\title{
Dansk lyrik og litteraturvidenskab efter 1990
}

Der er flere måder at vurdere en genres betydning på. Mens de store forlag og avisernes kultursider ofte er mest optagede af salgstal, på grundlag af hvilke man slutter, at den lyriske genres betydning er svindende, så ser det anderledes ud, hvis man anlægger en mere kvalitativ optik på den rolle, som lyrikken spiller inden for det litterære, kulturelle og forskningsmæssige felt som helhed. I denne forbindelse er der et aspekt, som sjældent er blevet berørt, og som derfor skal diskuteres i det følgende, nemlig lyrikkens intensive parløb med moderne litteraturvidenskab, forstået således at et særdeles stort antal af litteraturforskningens nybrud siden 1990 er sket i samklang med udviklingen inden for den poetiske genre.

Jeg skal her på ingen måde underkende prosaens forbindelse med moderne litteraturteori og -kritik. Det sidste årtis studier i narratologi med fokus på bl.a. udsigelsen og forfatterpersonens status bekræfter prosaens vigtige rolle. Alligevel vil jeg hævde, at lyrikken er den genre, der har korresponderet med de vigtigste og mest toneangivende teoretiske og metodiske innovationer, man har set inden for litteraturvidenskaben i de seneste årtier.

Spørgsmålet om forholdet mellem litteratur og litteraturteori eller -kritik er naturligvis komplekst. Det eneste, der synes sikkert, er, at påvirkningen i vid udstrækning går begge veje, og at det i mange tilfælde er vanskeligt at afgøre, hvad der er årsag og virkning. Et klassisk eksempel på dette kunne være forholdet mellem nykritikken og den modernistiske digtning, og skal man afgøre om kritikere eller forskere som Georg Brandes, Sven Møller Kristensen og Torben Brostrøm har haft større betydning for dansk litteratur end forfattere som Henrik Pontoppidan, H.C. Branner og Klaus Rifbjerg har haft for litteraturforskningen, er man i den samme type af problemer. Det er desuden vigtigt, at jeg i det følgende hverken vil påstå, at lyrikken på håndfast vis har påvirket litteraturteorien, således at denne har forandret sig, eller at litteraturkritikkens principper har styret digternes måde at skrive poesi på. Jeg vil derimod hævde, at der er tale om en parallel udvikling, som tydeligvis manifesterer sig i både litteraturen og kritikken med hensyn til opfattelsen af fundamentale be- 
greber som værk, udsigelse, stil, litteraturhistorie, genre og kunstart.

I det følgende bliver der stillet skarpt på dansk lyrik og litteraturvidenskab efter 1990. Min diskussion prætenderer langtfra at have medtaget alle aktører og værker fra dette felt, men nok at give et rids af en række hovedtendenser.

\section{Dekonstruktion}

Den amerikanske dekonstruktion vinder fodfæste i dansk litteraturkritik i 1990'erne med inspiration fra bl.a. Paul de Mans essaysamlinger The Rhetoric of Romanticism (1984) og The Resistance to Theory (1986), Barbara Johnson: A World of Difference (1986) samt Jonathan Culler: On Deconstruction (1983). I dansk sammenhæng optræder dekonstruktionen i en række antologier såsom Tania Ørum (red.): Til værks. Dekonstruktion som læsemåde (1994), samt i talrige dekonstruktivt orienterede afhandlinger som Jan Rosiek: Figures of Failure (1992), Carsten Madsen: Om læsning (1995), Thomas Bredsdorff: Med andre ord. Om Nordbrandts poetiske sprog (1996), Peer E. Sørensen: Udløb i uendeligheden. Læsninger i Sophus Claussens lyrik (1997) og Dan Ringgaard: Den poetiske lækage. Sophus Claussens lyrik, rejsebøger og essayistik (2000).

Dekonstruktion er, som Derrida understregede, ikke en metode, men en række læsestrategier, hvor hævdvundne kategoriseringer og begreber anfægtes. Man finder således også et særdeles bredt spektrum af dekonstruktive læsninger. Alligevel har denne litteraturkritiske retning visse fællestræk, nemlig at den i overvejende grad knytter sig til den lyriske genre, og at der specielt er tre problemstillinger, som står for skud. Den første problemstilling vedrører opfattelsen af digtet eller det litterære værk som en helhed, den anden er spørgsmålet om det lyriske jegs status, den tredje omhandler retoriske figurers og tropers betydning og status i forhold til hinanden.

Spørgsmålet om værkenheden diskuteres bl.a. indgående i de to Sophus Claussen-afhandlinger, Peer E. Sørensen: Udløb i uendeligheden (1997) og Dan Ringgaard: Den poetiske lækage (2000). Mest radikal er Sørensen, der i sin bog har den gennemgående tese, at man i Claussens poetiske tekster finder to forskellige æstetiske strategier, der peger forskellige steder hen litteraturhistorisk. Det hævdes i en række af Sørensens læsninger, at en enkelt af digtets strofer "er stærkere end helheden" og "peger ud over værkets sammenhæng” (Sørensen 1997: 35).

Et typisk eksempel på Sørensens analysestrategi vedrører Claussens digt "Balaften". Interessen koncentrerer sig her om digtets slutstrofe: "Hvad er der saa sært som en Lygte ved Dag, / naar blankrudet, bleg og forsovet / den løfter mod Lyset i udslukt Ro / sit fine og tænksomme Hoved -?" Hovedpointen i Sørensens analyse er, at denne strofe markerer et brud "med de foregående strofer", idet den består af "en række billedelementer, der helt overskrider de forrige strofers anslag" (ibid. 21, 14 og 16). Om de første 14 strofer i "Balaften" anføres det derimod, at "digtet er trygt indfældet i verden" (ibid. 14). Der er således, påstås det, tale om en skarp modsætning mellem to forskellige former for poesi, idet den afsluttende strofe har et arbitrært forhold til det stykke traditionel poesi, som den første del af digtet repræsenterer, da strofe 15 ikke skal "være andet end poesi: en genstand, 
der udsender et blegt sitrende lys - skønhed" og derfor "modsætter sig traditionel fortolkningskunst" (ibid.17). Det er ifølge Sørensen meningsløst at anlægge en helhedsbetragtning i forhold til digtet, da "digtets ord" ganske vist opretter "en korrespondance mellem lygten, jeget og kvinden fra de foregående strofer - men det er en korrespondance uden dybsind" (ibid. 15f). Og så er banen ryddet til en læsning af digtet, der består i at lægge den ene besværgende formel for den påståede poésie pure i "Balaften"s sidste strofe oven på den anden. Der er tale om, at "hele digtet egentlig er til for denne sidste hemmelige figurs skyld", at "slutstrofen [...] søger et sprog befriet for dagligdagens restriktioner, et sprog, hvis raison d'être beror på suggestive lyde og forførende rytmer", at vi i denne slutstrofe ser, "hvordan verset befrier sig for tyngden af det allerede artikulerede og træder ind i en verden af fjern skønhed", "en opak skønhed, et meditationsobjekt", at digtets slutstrofe "reaktualiserer" "forskellige skitser til en forestilling om 'ren poesi", at "denne forunderlige slutstrofe" udtrykker "en antydningens og flertydighedens poetik", at strofen "bliver dunkel [...] for at artikulere det endnu ikke artikulerede, det begrebsløse" (ibid. 18, 19,20 og 21) etc.

De elegante formuleringer kan dog ikke skjule, at det drejer sig om en problematisk analyse, idet man i høj grad kan betvivle den påståede manglende korrespondance mellem digtets første 14 strofer og dets afslutning, som er Sørensens pointe. I digtet hører vi, at "Leonora, den blege Kusine, staar / i Silke med hoved paa skraa og grunder, / Øjnenes Mørke spøger saa fjernt, / som ruged hun stum paa en Drøm, der gik under. // Den fine Pande bag brunsort Haar / og disse Øjne saa trofast-sære" (str. 6-7). Og senere fortælles Leonora, at "den som er venligst og dybest i Sorg, / sin Vellyst vidunderligst fatter" (str. 12). At denne sjæleskildring rummer en tragik, en dybde og en kompleksitet, som det kan virke malplaceret at kalde en "skær provinsidyl", synes åbenlyst. Og at lygtevisionen i strofe 15 korresponderer med og er motiveret af sjæleskildringen i strofe 6 og 7, er ligeledes oplagt. Det "blege", "sære", "fine", "tænksomme" (str. 6: "Hoved paa skraa og grunder") og den "udslukte ro" (str. 6: "ruged hun stum paa en Drøm, der gik under") er foregrebet i strofe 6 og 7, hvorved der er en poetisk raffineret, men samtidig ret enkel og i et og alt fænomenologisk-eksistentielt motiveret metaforisk operation, når Leonoras skikkelse på afstand ses som en lygte. Påstanden om at digtets slutstrofe "rykker digtet af dets hængsler", og at det "rummer billedelementer, der overskrider de forrige strofers anslag", holder på denne vis ikke, og det "dunkle", "gådefulde", "hemmelige", "begrebsløse", "endnu ikke artikulerede”, som Sørensen påpeger, er kort og godt mere et programmatisk dekonstruktivt statement end en konklusion med ophav i en konsistent læsning af Claussens digt.

Det andet kardinalpunkt i den dekonstruktive kritik vedrører spørgsmålet om det digteriske jegs status. Noget sådant diskuteres med skarp profilering i Sørensens gennemgang af "Parken og Staden". Som i tilfældet med andre digte anskues også denne tekst i et poetologisk spændingsfelt mellem rationalistisk, retorisk håndværkeræstetik og grænsesprængende moderne æstetisk erfaring af det "pludselige", det "sublime" etc. I "Parken og Staden" repræsenteres Sørensens to fortolkningspoler ved henholdsvis "et traditionelt stykke tidskritik på grænsen til kitsch og komik, grelt kontrasterende og i sin udførelse rutinepræget" og en balancering "på kanten 
til stumhed" og en overskridelse af "fornuftens og værkets grænser" (ibid. 79 og 84). Men hvordan får Sørensen så viftet hele den fænomenologiske vinkel på digtet som udtryk for en eller anden form for omverdensoplevelse af vejen? Ja, i dette tilfælde gælder det ikke bare som i "Balaften", at det er en enkelt strofe, som hævdes at sprænge sig ud af værkkonteksten. Derimod er det hele digtet, der angiveligt skulle undvige det "traditionelle nærværselement", idet det lyriske jeg er en identitetsløs "shifter", "der markerer udsigelsens afpersonaliserede fokus" (ibid. 85 og 79). Sørensen fastslår dette med en parafrase af en af de genkommende formuleringer fra Paul de Man: "I denne jagt efter det, der betinger digtet, sløres fænomenologiseringen af den lyriske stemme. Derfor også det identitetsløse ved udsigelsesinstansen. [...] Læseren kan derfor ikke uhindret gennemføre den forvandling af tekstens ord til antropomorfe fænomener, som den lyriske læsning i almindelighed hviler på. Tilsvarende er afpersonaliseringen af den lyriske stemme et forsøg på at undgå den jegbårne monolog, der kendetegner det lyriske" (ibid. 84f).

Spørgsmålet er imidlertid, om udnævnelsen af det lyriske jeg til en "shifter" er plausibel, eller om man tværtimod må sige, at man i "Parken og Staden" møder et komplekst lyrisk subjekt, der er integreret i det poetiske univers. Der er således en klar og uafviselig korrespondance mellem på den ene side jegets sindstilstand af regressiv kontemplation og på den anden side den stemning af dekadent-melankolsk sorg-begær, som knytter sig til omverdenssansningen.

Argumentet om den afpersonaliserede udsigelsesmodus findes talrige andre steder i den dekonstruktive kritik. Det forekommer ofte i kombination med refleksioner over en af dekonstruktionens yndlingsfigurer, apostrofen. Apostrofen diskuteres i dansk litteraturkritik med reference til Jonathan Cullers toneangivende artikel "Apostrophe" (1981) bl.a. i Hans Hauge: "O, mening. Om apostrofen hos N.F.S. Grundtvig, Jakob Knudsen og Henrik Nordbrandt” (1994) og min "O nitroglycerin! Apostrofiske former i ny dansk lyrik” (2001). I Hauges artikel anføres det fx om et digt af Henrik Nordbrandt: “'O' gør digtet til digt. Alle andre verslinjer end denne er rent referentielle, men i denne krydses digtet på tværs af the lingvistic moment, og det gør, at vi ikke kan naturalisere det" (Hauge 1994: 73). Forsvundet er altså med et pennestrøg - eller rettere med en apostrofe - den fænomenologiske dimension i digtet, der i sit sproglige øjeblik gøres til en ren retorisk funktion. En modargumentation i forhold til Cullers, Hauges og min diskussion af apostrofen som en fast bestanddel og en afgørende genrekonstruerende funktion i lyrikken kunne være, at grænserne mellem egentlige klassiske apostrofer og alle mulige moderne interjektioner og tiltaleformer er blevet særdeles flydende, og at talrige moderne digte har en anderledes kompleks udsigelsesmodus, end apostrofe-udsigelsen implicerer.

Spørgsmålet om apostrofens funktion hænger sammen med endnu et generelt emne i den danske dekonstruktive lyrikkritik, nemlig overvejelserne over forskellige tropers og figurers status i digtningen. I Thomas Bredsdorff: Med andre ord (1996) lanceres den dekonstruktivt inspirerede tese, at henholdsvis symbolet, metaforen og allegorien er typer af billedsprog, som skulle være dominerende i hver af de tre litteraturhistoriske epoker, romantik, modernisme og postmodernisme, og at man derfor for Nordbrandts vedkommende skulle kunne registrere en forkærlighed for allegorien. Bevismaterialet, der består i fremlæsninger af nogle allegorisk ori- 
enterede billedsproglige mønstre hos Nordbrandt, er dog ret spinkelt, ligesom det kan synes vanskeligt at få øje på det specifikt postmodernistiske hos Nordbrandt. Et andet dekonstruktivt orienteret retorisk fokus vedrører troperne, sammenligningen og metonymien, som det f.eks. diskuteres i Dan Ringgaard: Nordbrandt (2005), hvor det fremhæves, at en central del af Nordbrandts æstetiske strategi består i at anvende henholdsvis metonymien og sammenligningen frem for den klassisk modernistiske mestertrope, metaforen: "Sammenligningen fjerner sig ikke som en åbenbaring fra tid og sted, men skaber distance til en genkendelig virkelighed. [...] Med sammenligningen holder Nordbrandt afstand til en romantisk forestilling om poesien som et autentisk udtryk for overvældende følelser, en forestilling som metaforens fortalere langt op i modernismen ellers deler" (Ringgaard 2005: 101). Også min "Metonymien i moderne lyrik" (2003) fremhæver med dekonstruktiv inspiration, at metonymiens betydning har været undertrykt i kraft af, at metaforen er blevet opfattet som den dominerende trope i moderne lyrik, og at det måske kunne være rimeligt også at pege på en "metonymi-modernisme" hos en række danske digtere fra Tom Kristensen over Rifbjerg til Tafdrup frem for altid at tale om en metaformodernisme.

Skal man vurdere dekonstruktionens betydning i forhold til dansk lyrikkritik, vil jeg overordnet konkludere, at den er langt stærkere i sit idékoncept end i sine læsninger. I diskussionerne af værkenhed og det lyriske jegs status mangler der ofte belæg i teksterne for de radikale teser, der lanceres, mens man i tilfældene med bestemte tropers manifestation i specifikke forfatterskaber kan tale om en overeksponering af retorikkens betydning. Det er ikke nok at identificere troperne som udtryk for en bestemt retorisk strategi, men ligeså vigtigt at betragte disse som tekstelementer, der indgår i et samspil med andre sproglige udtryk, og som kommunikerer bestemte sansninger, holdninger og omverdenskonceptioner.

Det er dog bemærkelsesværdigt, at den dekonstruktion, der ofte har givet et begrænset udbytte i læsningen af ældre lyriske forfatterskaber, på markant vis er i overensstemmelse med en række af de vigtigste danske lyriske forfatterskaber fra 1990 og fremefter. Man kan sige, at de indsigter, der spidsformuleres i de dekonstruktive læsninger, er blevet alment udbredte i store dele af digtningen fra de seneste år. Dette gælder således for forestillingerne om, at værket kan være polyfont $\mathrm{i}$ sin intertekstuelle dialog med andre tekster og uafgrænseligt som form, at det kan indeholde et labilt og udefinerbart jeg, der kan have karakter af at være en "shifter", og at troper og figurer kan indgå i komplekse synteser, hvor de kan forholde sig ironisk eller travesterende i forhold til den funktion, de havde i retorikken.

Betragter man f.eks. Ursula og Julie Andkjær Olsen: Have og helvede (2010), møder man et udpræget uafgrænseligt og polyfont værk. Med polyfont hentydes der ikke blot til, at værket har to forfattere, idet Julie Andkjær Olsen som billedkunstner bidrager med eksperimenter med typografi, billeder og opsætning, der samvirker med skriften i kompositionen, men også at værket som Ursulas øvrige værker rummer en række tekstspor eller stemmer, der interagerer.

De tre stemmer og grafiske spor i bogen er benævnt henholdsvis "havefornemmelser", "slangens bog" og "navnløs". De har tre forskellige stilarter og udtrykker hver især tre psykologiske tilstande, som er knyttet til en række kulturhistoriske 
fænomener. "Havefornemmelser" er en uskyldstilstand, hvor tingene ikke har fået navn, og hvor det enkelte menneske endnu ikke er blevet underlagt en samfundsmæssig tvang. Illustrationerne i denne sekvens viser antik kunst og billeder af dyr og planter i rolige pastelfarver, og skriften er en letlæselig og stilfuld grøn håndskrift. Ursulas diktion er i dette spor ladet med al den klassiske poesis længsel efter helhed, sammenhæng, individuel realisation og utopisk væren og udtrykker sig i smukke og vise formuleringer som de følgende: "retfærdighed kræver forestillingskraft / kræver pynt / overflod / digt / ikke afsløring [...] i en have hvor alting har navn er intet muligt."

Helt forskelligt fra "havefornemmelser" er afsnittet "slangens bog", hvor skriften er sat med sting som i det berømte Bayeux-tapetet, og hvor man på illustrationssiden finder middelalderlige tegninger af kamp, slanger og uhyrer. Dette grafiske design afspejler skriftens fortælling om menneskets oplevelse af at blive underlagt en tvang og en styring fra det sociale. Slangen skal tydeligvis ses som et symbol på de sociale, ensrettende kræfter. Hør blot den følgende diabolsk-satiriske vending: "Slangen voksede og den fik flere og flere navne: [...] udover stat og individ også det private erhvervsliv og hæren af dem som kæmper om magten og æren og den store bil med fjernsynet i. Og slangen blev ved med at udbygge med netværk, incitamentsstrukturer og projektansættelser."

Endelig har vi det tredje spor i Have og helvede, hvor den grafiske form består af en kollage af udklippede bogstaver og billeder, der i sandhed afspejler en hæslig og meningsløs modernitet. Her kombineres billeder af færdigretter og glansbilledengle, og skriften har til formål at udtrykke den desperation og fremmedgjorthed, som et moderne menneske, hvis omgivelser kun består af tomt konsum, føler: "Dårlig dårlig have. Fortæl mig! Jeg er massen så hvorfor er jeg så ensom? Fortæl mig nu!"

Vi får altså i Andkjær Olsen-værket en kompleks diagnose af det moderne menneske og dets udvikling og dilemmaer, hvor den dekonstruktive indsigt $i$, at der ikke findes sande og endegyldige udsagn, besejlet af et autoritativt og autentisk subjekt, i høj grad udgør en grundlæggende præmis.

En anden af tidens markante digtere, hvor en sådan dekonstruktiv indsigt er fundamental, er Sternberg, hvis poetik også præcist udtrykkes i titlen på hans digtsamling, Et punkt overrendt af ingenting (2011). Blandingen af genrer, stilkoncepter og udsigelsesmodi er her selve motoren i den poetiske skabelse, som det ses i den følgende dybsindige, sjove, underfundige og rørende tekst, hvor den personlige brevgenre på absurd vis interagerer med de kosmiske hymner fra den amerikanske poesis patriark:

kære walt whitman

du skrev at jeg

imens jeg læste

det du skrev

ville tænke over

hvor glad jeg ville være

hvis vi kunne blive venner 
for at fortælle dig

at det gjorde jeg

Blandt talrige andre nyere digtere, der har integreret dekonstruktive indsigter i deres digtning, kan man nævne Per Aage Brandt, Peter Laugesen, Claus Carstensen, Mette Moestrup, Martin Glaz Serup, Niels Frank, Lars Bukdahl, Olga Ravn, Lars Skinnebach, Marius Nørup Nielsen, Asta Olivia Nordenhof og Christina Hagen.

\section{Fænomenologi}

En fænomenologisk modposition i forhold til dekonstruktionen kan registreres med Horace Engdahls indflydelsesrige Beröringens $A B C$ (1994), der også udgives på dansk i 2004, som et startskud. I sin essaysamling markerer Engdahl en kritisk holdning til den dekonstruktive tendens til, at tekster reduceres til rene retoriske spil. Der polemiseres her uden specifik adresse, men ikke uden krukkeri, mod "de katedraler af ironi som forvovne dekonstruktivister har rejst på spidsen af et enkelt ord eller skilletegn" (Engdahl 2004: 108). Alternativet er en læsningsstrategi, hvor man orienterer sig mod, hvad der benævnes, "formen af en stemme" (ibid. 12). I Engdahls fremstilling bliver retorik altså et negativt ladet begreb, idet det dækker over en pragmatisk overtalelseskunst, og stemmen kan modsat identificeres som det i teksten, der med størst mulig konsekvens søger bort fra det retoriske eller overtalende. Engdahl anvender et nøglebegreb om denne tendens inden for digtningen, nemlig "det ikke-emfatiske".

Birgitte Steffen Nielsen har i sin Tranströmer-afhandling Den grå stemme. Stemmen i Tranströmers poesi (2002) forsøgt at frugtbargøre Engdahls idé om en "ikkeemfatisk henvendelse" eller "distraherende modstemme" i forhold til en læsning af Tomas Tranströmers lyrik (Nielsen 2002: 110 og 13). Hun fremhæver her, at Tranströmer-receptionen - repræsenteret ved monografier af bl.a. Kjell Espmark og Niklas Schiöler - har været karakteristisk ved næsten udelukkende at koncentrere sig om billedsproget i digterens værker. Man har med Nielsens ord opfattet Tranströmers digtning som "centrallyrisk billedmageri uden egentlige modhager i det fuldendte", og Nielsen ønsker i stedet i sin Engdahl-inspirerede afhandling at "være opmærksom på digtenes gråligt lysende modstemmer", der "kaster grus i billedmageriet" (ibid. 13 og 15). En primær inspiration for Nielsens tanker er, at Engdahl i en anmeldelse af Tranströmers Fra levande och döda (1989) har den tese, at denne samling repræsenterer et brud i forfatterskabet, hvor billedet - som det hedder i Engdahls patosladede stil - "har måttet vige for stemmen som sandhedens bærer i hans digte" (ibid. 25). Den engdahlske pointe hos Nielsen er, at der sker en reduktion af betydningspotentialet i Tranströmers tekster, når man udelukkende på centrallyrisk-modernistisk vis fokuserer på digtereksistensen som en "observatør" med et "metaforfindende blik" eller - som Espmark foreslår - "illuminerede øjeblikke" og "saglige epifanier" (ibid. 34 og 40). At man altså skal søge efter noget mere eller andet i Tranströmers poesi end det emfatiske billedsprog, fors $\varnothing$ ges herefter appliceret i Nielsens Den grå stemme. 
Det er oplagt, at den engdahlske idé om "en stemme" i teksten er udtryk for en anden forståelse af den poetiske udsigelse, end den man finder i såvel nykritikken, hvor man forestiller sig, at der er en stilistisk homogenitet og monologicitet i det udsagte, som i dekonstruktionen, hvor man afviser den poetiske udsigelses autenticitet som en retorisk konstruktion. I Engdahls luftige formuleringer om "en stemme" er der, så vidt man kan skønne, et fokus på flertydighed, ironi og uafgørlighed med hensyn til det udsagte, hvilket også korresponderer med tanken om en interaktionslyrik, der indeholder stilistisk heterogenitet og flerstemmighed, som jeg har diskuteret i Drømme og dialoger (2009).

At Engdahls Blanchot-inspirerede idé om "digtningens stemme" grundlæggende har et særdeles abstrakt og uhåndgribeligt præg, er en anden sag. Man hører, at "stemmen er det der forsvinder når teksten udlægges", at man skal "lytte efter den fjerneste tone i teksten", og - om Björling - at "vi finder hos ham en dybere indsigt i stemmens mysterium end hos nogen anden moderne forfatter" (Engdahl 2004: 135ff.) I sidste ende må "stemmen" på denne vis - hvis man bortskærer alle mysticismer - være udtryk for bagvedliggende intentionalitet af samme type, som når Cleanth Brooks taler om, at et litterært værk rummer "a total and governing attitude" (Brooks 1947: 206f.), Wayne Booth om "the implied author", hvorved der forstås "an intuitive apprehension of a completed artistic hole" (Booth 1983: 73), og Jørn Vosmar om "værkets holdning" eller "måde at have verden på" (Vosmar 1969: 80f.).

Med referencen til Jørn Vosmar er vi inde på en bølge af fænomenologisk kritik - igen med et hovedfokus på lyrikken - som manifesterer sig fra begyndelsen af 00'erne. Vosmars artikel "Værkets verden, værkets holdning” (1969) bliver taget op og udgør sammen med Roman Ingardens klassiker Das literarische Kunstwerk (1931) samt værker af fænomenologiens ophavsmænd Husserl, Heidegger, Merleau-Ponty, Sartre og Mikel Dufrennes byggeklodserne i en række danske fremstillinger om fænomenologisk litterær analyse såsom Thomas Illum Hansen: Tidens øje - Rummets blik (2001), Bo Hakon Jørgensen: Intentionalitet - om litterær analyse på fænomenologisk grundlag (2003) og Susanne Kemp: Appeller. Astetik i det 20. århundredes danske lyrik (2010). I pagt med denne orientering er desuden Dan Zahavis fremstillinger om Husserl og fænomenologien generelt samt Atle Kittangs diskussion af de fænomenologisk orienterede billedsprogsteorier hos Sartre, Blanchot og Bachelard i "Det billedmæssige" (1998).

I Bo Hakon Jørgensens Intentionalitet fremlægges Ingardens model over det litterære værk, der anskues som bestående af fire lag eller strata, nemlig ordlydlaget, betydningsenhedernes lag, aspekternes lag og genstandslaget. Alle disse lag er hos Ingarden karakteristiske ved, at de er strukturerede i forhold til en overordnet intentionalitet. Jørn Vosmar benævner denne intentionalitet "værkets holdning”, og den måde, hvorpå værkets elementer organiseres, giver han det Heidegger-inspirerede udtryk: "værkets verden." Vosmar er på én gang reduktiv og videreudviklende i forhold til Ingardens model. Reduktionen sker, idet Vosmar kun benytter sig af genstandslaget i sin bestemmelse af værkets holdning. Til gengæld præsenteres ideen om genstandslagets fremtræden i værket på meget udfoldet vis, eftersom Vosmar med Heidegger som referenceramme - ser dette som gestaltet af fire eksistentialer: 
tid, rum, omverden og jeg - der udgør "de fire fundamentale og irreducible faktorer i vor oplevelse og dermed i vort forhold til tilværelsen som totalitet" (Vosmar 1969: 80).

Jørgensen opstiller i Intentionalitet, hvad han kalder, en "spørgemodel", hvor pointen er, at en række spørgsmål på fænomenologisk vis forsøger at mime den tilegnelsesproces, der foregår hos en læser fra den første umiddelbare oplevelse af teksten til det afsluttende punkt, hvor der er sket en analytisk fiksering af værket som æstetisk objekt. Han applicerer sin læsestrategi, som også kaldes "søgende rundgange om teksten" (ibid. 67), på en række tekster af bl.a. Adam Oehlenschläger, Paul la Cour, Per Højholt, Pia Tafdrup og Peter Adolphsen. Og der er en klar parallel - alle forskelle ufortalt - mellem Jørgensens fænomenologiske og Peer E. Sørensens dekonstruktive læsestrategier, nemlig at ingen af dem reflekterer over det forhold, at deres analytiske vinkel passer bedre til nogle tekster end til andre. Ligesom Sørensens dekonstruktive paradigme om et opbrudt værkbegreb og det lyriske jeg som en retorisk konstruktion ofte passer dårligt til Claussens symbolistiske centrallyrik, passer Jørgensens fænomenologiske eftersøgning af en intentionalitet - eller med Engdahls begreb "en stemme" - langt bedre på en klassisk centrallyrisk tekst end på en avantgardistisk interaktionslyrisk.

Når man møder tekster, der indeholder sammenstød mellem forskellige diskurser, opstår der problemer med den type analytisk afkodning, som præsenteres i Intentionalitet, hvis mål er at finde et samlende perspektiv for teksten. I Jørgensens læsning af Højholts “Domkirken i Nørre-Snede" (1988) overses det, at tekstens pointe er, at to inkommensurable sprogregistre mødes og konfronteres, nemlig en arkaiseret lyrisk patosladet stil ("domkirken", "grødede mørke”, "søvnige lys", "Kirkeageren") og en moderne stil, hvis kontekst er den moderne kommercialiserede og materialistiske verden ("erhvervschauffører", "cafeteriet i Vejle", "lokale entusiaster" etc.). Mens Jørgensen læser teksten som en centrallyrisk dybdestruktur, hvor udtrykket "erhvervschauffører" hævdes at have en symbolsk betydning, så er pointen derimod, at vi i en sådan interaktionslyrisk tekst har sideordnede sprogregistre, der lader betydningen være uafklaret. Den fænomenologiske søgen efter én samlet intentionalitet bliver skæv i forhold til Højholts tekster, når denne digter af Jørgensen enten læses som en parodierende spasmager (som i analysen af "M/S Nelly i modlyd" fra Primitivitetens paradoksale kostume (1986)) eller som en heroisk sensymbolist (som i analysen af "Domkirken i Nørre-Snede" fra Intentionalitet), hvor teksten overordnet forstås som en "allegori på kunstnerisk arbejde" (ibid. 83). Alternativet til en sådan opfattelse er at hævde, at fascinationskraften i Højholts tekster ofte beror på, at både det patosladede symbolistiske $o g$ det postmodernistisk parodierende er til stede i den samme tekst, der hermed fremstiller et uforløst sammenstød mellem stilarter og livstolkninger.

Vil man derimod se på, hvor fænomenologien har vist sig som en særlig frugtbar teoretisk og analytisk forståelsesramme, må man, som det bl.a fremgår af Susanne Kemps Appeller, gå til den centrallyriske tradition spændende fra Sophus Claussen og Johannes V. Jensen til Søren Ulrik Thomsen og Pia Tafdrup. Hos disse forfattere er jeget et indiskutabelt centrum i det digteriske univers, den poetiske stemme har et stærkt præg af autoritet og autenticitet, og den poetiske tekst, der er formuleret $\mathrm{i}$ 
et poetiske særsprog, fremtræder som koncentreret og afgrænset i forhold til andre tekster. Denne karakteristik korresponderer også med markante dele af den lyrik, der udkommer i disse år fra etablerede forfattere som Tafdrup, Thomsen, Nordbrandt, Sten Kaalø, Simon Grotrian, Janus Kodal, Lene Henningsen og Nicolaj Stochholm.

Et eksempel kunne være Nikolaj Stochholms Ødelagt rim (2013). I Stochholms centrallyrik er omdrejningspunktet altid et jeg, men dette jeg er underkastet en konstant udforskningsproces - ofte fyldt med vrængende selvironi og sarkasme - hvor der reflekteres over jegets forhold til sit sprog, sit sjæleliv og sine omgivelser. Vi bevæger os mellem sydlige himmelstrøg og dansk frostvejr, mellem fortvivlelse og forelskelse, og mellem barstole og kirkesæder. Der er hele tiden drøn på, og vi har at gøre med en poesi, der aldrig bliver selvfed eller patetisk, som man ser det i visse lyriske forfatterskaber, hvor fokus konstant er på digterens identitet og den poetiske skabelsesproces. Dette skyldes også, at Stochholms værk rummer en raffineret humor. Alene titlerne på digtene er poetiske fund som i tilfældet med "Onlinesygen i København", "Sms fra jeget", "Staten kommer" og "Digtet som idiot". Det drejer sig om effektfulde tekster, hvor billeddannelser i arabeskagtige strukturer udvikler sig til scenarier, hvor før og nu, her og der, og indre og ydre blander sig med hinanden. Stochholms rastløse og længselsfulde subjekt ytrer sig desuden om en religiøs dimension i tilværelsen. Et digt hedder "Frelsens hær" og lyder:

6 Stavrende fra pol til pol kursen fra bar til bordel toppedes jeg med jeget selv på Sønder Boulevard en skramlet og skummel vinternat mellem kirken og trafikskiltet af sort sne

Klemt af timen trådte jeg ind i en mursten og hørte koret orkesteret der mødte alle toner mellem mig og den frosthærdet faldende mellem enhver mening og det absolutte ingenting

Jeg så et stormende ocean og jeg så et skib med en lysende kristus i stævnen og jeg så at havet var os mennesker bølgende fra dag til nat og jeg så at han bjærgede enkelte om bord. 
I teksten ser man den subtile selvironi, hvor et splittet subjekt ("toppedes jeg med jeget") skiftevis fremhæver og håner sin egen religiøse tilskyndelse ("mellem kirken / og trafikskiltet af sort sne"). Vi kan naturligvis godt med Peer E. Sørensens dekonstruktive optik tale om, at digtet peger i retning af to forskellige æstetiske konceptioner, nemlig en symbolistisk-religiøst farvet over for en nihilistisk-postmodernistisk. Dette betyder dog langtfra, at de to diskurser - modsat hvad vi så hos Højholt og Andkjær Olsen - kan udskilles i forhold til hinanden. Diskurserne indgår således snarere, som nykritikerne I.A. Richards, William Empson og Cleanth Brooks påpegede med deres centrale begreber "paradox", "ambiguity" eller "irony", i en kompleks og svært opløselig syntese i digtet.

Også blandt den yngste generation af digtere ses det centrallyriske, der på væsentlige punkter er i samklang med en fænomenologisk fortolkning. Et eksempel er Julie Sten-Knudsen: Hjem er en retning (2011). I Knudsens digte udforskes et kaotisk sjæleliv på en måde, der minder om det, som Erik Skyum-Nielsen i 1980'erne kaldte for kropsmodernisme, idet vi møder et rastløst jeg, der hele tiden søger tilbage til kroppens funktioner og sansninger som et minimumsbevis på, at digterjeget er til. Der er en voldsom dynamik over skriften, der hele tiden forskyder sig ned over siderne i korte prægnante udsagn, der skifter mellem erindring, refleksion, sansning og kropsoplevelse:

4 Blodprøven efterlod et stort blåt mærke midt på armen. Du må ikke bebrejde nogen at de ikke forstår dine drømme, de er mest interessante for dig selv. Men hendes indfaldne ansigt forfølger dig. En sødlig duft af råddent løv i luften.

En turkis klat tandpasta i håndvasken. Munden lungerne, hjertet, mavesækken, blæren, tarmene. Blodet pisker videre.

\section{Formalisme}

Formalismen er som fænomenologien en retning, der går tilbage til den første tredjedel af det 20. århundrede, og hvis kanoniserede teoretiske skrifter af bl.a. russerne Viktor Shklovskij og Roman Jakobson og tjekkerne Jan Mukarovsky og René Wellek har vakt genklang talrige gange i dansk litteraturkritik. Den formalistiske orientering har imidlertid først for alvor fået gennemslagskraft i dansk litteraturvidenskab efter 1990.

Den formalistiske orientering har i visse tilfælde forbindelse til dekonstruktionens anti-hermeneutiske koncentration om den litterære form og retorikken, uden at der dog i mange tilfælde kan spores nogen inspiration fra Paul de Man og Derrida 
m.fl. Ligesom dekonstruktionen og fænomenologien har formalismen hovedsageligt knyttet sig til den poetiske genre i sine teoretiske og analytiske pointer og kan lokaliseres i forhold til to forskellige områder. Det drejer sig om henholdsvis det rytmiske og det tropologiske.

Hvad angår det første, er en betydelig enmandsindsats i dansk sammenhæng begået af Jørgen Fafner med Klassisk og moderne verslære (1989) samt Dansk vershistorie I-II (1994-2000). Grundtesen i alle Fafners værker er, at der i verset er tale om "en sammensmeltning af to planer: en abstrakt ramme og en konkret udfyldning, et metrum og et hver gang individuelt vers, der inviterer til, afspejler og vekselvirker med metret, kort sagt: en takt og en tale" (Fafner 1989: 73).

En teoretiker, der på afgørende punkter har videreført Fafners argumenter i relation til nutidens umetriske digtning, er Frank Kjørup i Sprog versus sprog (2003). Kjørup gør et begreb, som kun spiller en mindre rolle i Fafners værker, nemlig "optisk enjambement", til selve essensen i moderne digte. Dette begreb henviser til, at man i forhold til de syntaktiske enheder benytter hårde og abrupte linjeskift. Kjørups sigte er at diskutere den betydningsproduktion, der fremkommer i digtet som følge af modsætningen mellem sproget og verset som grafisk form. Hans hovedtese er intet mindre, end at valget af linjeskift/ikke linjeskift må betragtes som det frie vers' væsentligste poetiske paradigme. Som et nøglebegreb anvender Kjørup betegnelsen "V-punkt" om de steder i et digt, hvor der optræder linjeskift. Kjørups afhandling er et udpræget specialstudium. Hermed menes, at der nok sker en overeksponering af 'V-punkts-pointen' ved at hævde, at V-punktet udgør paradigmet over alle med hensyn til at afgøre, hvor det poetiske i en tekst ligger. Man kan med god ret hævde, at andre poetiske virkemidler end enjambementet har lige så stor betydning, når man vil analysere en tekst med udgangspunkt i formalistiske kriterier. Dog er der ingen tvivl om, at Kjørups tese i en mere 'light' udgave, hvor det påpeges, at linjeskiftet eller "V-punktet" kan spille en afgørende rolle i forhold til et digts betydning og æstetik, er korrekt.

Interessen for de seneste årtiers digtning i Fafners afhandlinger er yderst begrænset, idet kun 25 sider ud af mere end 500 beskæftiger sig med litteraturen efter 1950. Lidt bedre ser det ud i de senere danske værker om rytme i poesien, såsom Kjørups samt Dan Ringgaard: Digt og rytme (2001). Den nyeste danske digtning er dog heller ikke specielt i fokus i disse værker, der begge mest interesserer sig for principielle og overordnede forhold ved poesien. I Kjørups og Ringgaards værker finder man i forhold til ny dansk poesi kun enkeltanalyser af Klaus Høecks, Pia Juuls og Niels Lyngsøs værker. Hos Ringgaard er der desuden i essayet "De bundne former og avantgarden" (2000) en pointering af, at man i den danske digtning omkring 2000 møder en "brug af bundne former", der kan fungere som "reservoir for ny formel eksperimenteren og ny poetisk sensibilitet" (Ringgaard 2000: 25). En nøjere uddybning af denne problemstilling får man dog ikke.

I Drømme og dialoger (2009) samt "Interaktionslyrikkens puls" (2010) har jeg forsøgt at sætte fokus på rytmens betydning inden for den nyeste lyrik. Jeg argumenterer for, at man har to forskellige principper for anvendelse af det rytmiske i digtningen, som knytter sig til henholdsvis en centrallyrisk og en interaktionslyrisk norm. Kodeordet for den første type lyrik er beherskelse, og der skabes værker, 
hvor en rytmisk form og et stof indgår i en syntese. Dette kan gøres ved at anvende tilrådighedstående poetiske former som sonetten (Pia Tafdrup, Inger Christensen, Sten Kaalø) eller terzinen (Niels Lyngsø), der ofte knytter sig til en overordnet, metafysisk farvet opfattelse af en samklang mellem det individuelle og det universelle. Modsat dette er der i interaktionslyrikken tale om en travesterende, humoristisk og ofte grov anvendelse af rytmiske og lydlige effekter. Det ideologiske grundlag for disse eksperimenter er dekonstruktionen og poststrukturalismen med deres prioritering af tegnet over betydningen. Man skaber i forlængelse af Højholt digteriske 'maskiner', hvor gentagelsen af ord (Niels Frank) eller en rytmisk figur (Per Aage Brandt) i et 'uafsluttet' serielt-proceduralt forløb bliver digtets motor. Og man dyrker en folkelig remse-, rim- og ordspilslyrik som en pendant til nyere amerikansk lyrikteoris afstandtagen fra en 'akademisk poesi'. Der er kun hos nogle af digterne (Bukdahl, Benny Andersen) tale om en romantisk farvet dyrkelse af det naturlige og primitive i remseæstetikken, mens der hos andre digtere (Peter Laugesen, Andkjær Olsen) optræder en ætsende kritik af sociale og poetiske konventioner.

Et eksempel på det sidstnævnte, hvor den rytmiske formalistiske teori på humoristisk vis optræder som en integreret del af nyere dansk lyrik ses f.eks. hos Mette Moestrup i Dø, løgn, dø (2011), fra hvilken en af de sarkastisk-parodiske remser i digtet "Min kittel (Arbejdersang)" lyder:

46 Min kittel er for kort, og det er noget lort, og hjernen går i sort. Hvad er det for en norm med sådan en uniform? Jeg knokler i en parodi på en fortærsket fantasi.

Med Moestrups travesti over de politiske kvindesange er vi også inde på en anden tendens i interaktionslyrikken, nemlig brugen af den mundtligt reciterende stil med dens remser og ordspil. Blandt forskningsværker på dette område har man Stefan Kjerkegaard: Ildspor. Ordspillet og dets funktion i Per Højholts, Simon Grotrians og Peter Laugesens digtning (2008). Kjerkegaard giver en bred, men analytisk funktionel, bestemmelse af fænomenet ordspil, der med undtagelse af en kort omtale i Ulla Albeck: Dansk Stilistik (1939) stort set ikke har været berørt i dansk litteraturkritik. Definitionen lyder: "et flertydigt spil med ordene, oftest på baggrund af deres lydlige beskaffenhed" (Kjerkegaard 2008: 14).

Kjerkegaard skelner mellem to funktioner, som ordspil kan have, idet det kan fungere som henholdsvis "sprogkritik" eller "sprogmagi". Med det førstnævnte menes der, at ordspillet anvendes " $i$ en kritik af sprogets meningsdannelse i det hele taget”. Der foregår her en sabotage af enhver form for på forhånd givne diskurser og konceptioner. I sidstnævnte tilfælde er der derimod en "tillid til sprogets pegen på noget radikalt andet" (ibid. 149). Sproget får med andre ord tillagt et magisk potentiale, idet det illuderer en kontakt med en eller anden metafysisk essens. De to positioner er i slægt med positioner, som man møder inden for på den ene side 
den angelsaksiske nykritik og den romantisk-symbolistiske poetik, på den anden side det poststrukturalistiske og dekonstruktive paradigme. Hvad forfattere angår, udspændes afhandlingen tilsvarende mellem to digtere, idet den nihilistiske skrifttematiker Højholt står for den sprogkritiske position, og den religiøse hermetiker Grotrian for den sprogmagiske, mens avantgardisten Laugesen repræsenterer en midterposition.

At Kjerkegaards formalistiske bestemmelse af ordspillet er i samklang med meget store dele af den danske poesi fra de sidste årtier, er åbenlyst. Man kan blot bemærke, hvor centralt ordspillet står i forfatterskaber som Klaus Høeck, Per Aage Brandt, Viggo Madsen, Janus Kodal, Morti Vizki, Pia Juul, Lene Henningsen, Lars Bukdahl, Lone Hørslev, Ursula Andkjær Olsen, Martin Glaz Serup, Olga Ravn og Asta Olivia Nordenhof.

\section{Litteraturhistorisk kontekstualisering}

Mens dekonstruktionen, fænomenologien og formalismen som litteraturkritiske strømninger i de sidste årtier hovedsageligt har haft fokus på det enkelte poetiske værk, har der tilsvarende været en intention om at sammenkæde flere værker og forfatterskaber eller forbinde disse med en samfundsmæssig og historisk kontekst. Den dominerende kategori i dansk litteraturhistorie frem til 1970'ernes slutning var "perioden", hvor f.eks. Sven Møller Kristensen i en række værker lavede synkrone snit, der ordnede forfatterskaber under etiketter som Impressionismen i dansk fiktionsprosa 1870-1900 (1938), Den dobbelte eros (1966) og Den store generation (1974). Så kom 1970'erne og 1980'erne med Foucault, Lyotards aflivning af "store fortællinger" og New Historicism, hvorefter det blev legalt for den enkelte litterat at konstruere sin litteraturhistorie eller, som det ofte hedder, "linje" i dansk digtning.

I dansk litteraturkritik fra de seneste årtier finder man et stort antal værker, der søger at rokke ved hævdvundne litterære konceptioner og/eller at opstille nye. Det er her som med de tre førnævnte kritiske strømninger lyrikken, der i overvældende grad tages som udgangspunkt i disse fremstillinger. ${ }^{I}$ I forbindelsen med konstruktionen af lyrikhistoriske "linjer", kan man naturligvis med rette pege på, at der indgår et subjektivt element i valget af de forfatterskaber og digte, der kædes sammen, og man kan ofte diskutere rimeligheden af de "linjer", "traditioner", "motiver" eller "historier", som opridses. På den anden side er der en klar styrke ved de komparative lyriklæsninger, hvor flere værker sættes i et eksperimentelt modsætningsforhold til hinanden. Man undgår nemlig her problemet fra de værkcentrerede studier, hvor et værks specifikke træk ikke sammenlignes med andre værkers, og hvor det derfor kan være vanskeligt at sige, hvilken vægt man skal tillægge de fænomener, man registrerer i et værk.

En litteraturhistorisk indsats med korrelation til dansk lyrik er også blevet leveret med en mere dekonstruktiv tilgang til de litteraturhistoriske begreber. Det gælder i forhold til de store begreber 'symbolisme' og 'modernisme'. Peer E. S $\varnothing$ rensen har i Udløb $i$ uendeligheden argumenteret for, at symbolisme i dansk sammenhæng er en betegnelse, der ikke har nogen substans, og at den kun kan anskues som "et transitsted mellem 1800-tallets 'romantiske' digtning og modernismen og 
avantgarden" (Sørensen 1997: 188), mens Anne-Marie Mais “The Thrill of It All. Modernismen som mangearmet blæksprutte" (1998) og Anne Borups "Den danske modernismekonstruktion" (2000) hævder, at brugen af begrebet modernisme, eller med Kolding-forskernes yndlingsudtryk "modernismekonstruktionen", ender med "at kvæle forståelsen af nyere dansk litteratur" (Mai 1998: 14f.). Har disse fremstillinger deres slagkraft og relevans som debatskabende litteraturhistoriske indspil, så er deres svagheder dog, at de i vid udstrækning ser bort fra den tidligere nævnte forskning i lyrikhistoriske "linjer", hvor en international forskning med afsæt i henholdsvis symbolisme og modernisme bruges til at kaste nyt lys over en række værker og forfatterskaber. Sørensens og Mais/Borups kritik af begreberne symbolisme og modernisme blev stående ved en noget reduktiv og generaliserende kritik med afsæt i de to programmatiske artikler, Johannes Jørgensen: "Symbolisme" (1894) og Torben Brostrøm: "Det umådelige mådehold" (1959).

\section{Interartielle og intermediale lyrikstudier}

Mens en hovedtendens i den klassiske modernisme har været at forsvare genrernes og kunstarternes renhed, har en dominerende dagsorden $i$ kunst og kritik siden 1990 været at se på fusioneringen mellem genrer, kunstarter og medier. Et fokus inden for nyere kunst-, litteratur- og medieteori har da også været på forskellige måder, hvorpå kunstarter og modaliteter samvirker. Sammenhængen mellem kunstarterne kan imidlertid foregå efter tre grundprincipper, som det skildres i den mest omfangsrige nordiske antologi om det interartielle, nemlig Ulla-Britta Lagerroth m.fl.: I musernas tjänst. Studier i konstarternas interrelationer (1993).

Det første princip for mellemværender mellem kunstarter kan kaldes transformation og består i, at de forskellige kunstarter ikke er kombineret og optræder inden for det samme værk, men at der er en reference mellem disse. Det mest markante eksempel på noget sådant i relation til lyrikken er ekfrasen. I en ekfrase forholder teksten sig beskrivende eller reflekterende til et visuelt værk, der ofte befinder sig et andet sted end teksten. At eksfrasen har været et særdeles udbredt fænomen op igennem hele historien, er godtgjort i en lang række studier. I dansk og nordisk sammenhæng gælder det f.eks. Ole Karlsen: Ord og bilete. Ekfrasen i moderne norsk lyrikk (2003), Anette Fryd: Billedtale. Om mødet mellem billedkunst og litteratur hos Gunnar Ekelöf, Ole Sarvig og Per Højholt (2006), Cecilie Harrits m.fl. (red.): Ekfrasens former (2007) og Per Bäckström m.fl. (red.): Samspill mellom kunstartene. Modernisme i nordisk lyrikk 4 (2010).

Det andet kaldes kombination og består i, at flere forskellige kunstarter optræder side om side i det samme medie. Eksempler på dette er filmmediet, tegneserien, vokalmusikværker og en del internetlitteratur. Hvad angår lyrikken, har man i de seneste årtier set en tydelig tendens til tværæstetiske eksperimenter, hvilket er blevet belyst i Birgitte Stougaard Pedersen: Lyd, litteratur og musik - gestus i kunstoplevelsen (2008), Louise Mønster: "Samtidslyrikkens intermediale liv" (2012), Dan Ringgaard: Stoleleg. En bog om Jørgen Leth (2012) og undertegnedes "Nordisk poesi mellem bog og internet" (2012). Den nævnte lyrikforskning er fremkommet i et samspil med en lang række markante poesiudgivelser. Man kan nævne Christian 
Dorph: Popcorn (2000) og Christian Yde Frostholm: Mellem stationerne (2001), der er digtbøger, med hvilke der følger lydspor, og man kan fremhæve en række liveperformance-sessions, hvor digtere som Peter Laugesen, Nicolaj Stochholm, Jørgen Leth og Theis Ørntoft har optrådt med musikerbesætninger, eller hvor digtere har udgivet deres poesi i ren akustisk form som med Niels Lyngsøs rap-album Sigdetvidere (2011).

Med hensyn til det tværæstetiske felt har man desuden tendensen til at lade billedkunst indgå i en interaktion med det digteriske materiale. Af eksempler på noget sådant kan man nævne Naja Marie Aidt: Balladen om Bianca (2002), hvor Aidts tekster fungerer i et samspil med fotokollager af Kim Lykke, og Morti Vizki: Rejsebog (2002), i hvilken Vizkis tekster konfronteres med en række kollageværker af kunstneren Christian Skeel. Man kan betragte Søren Ulrik Thomsen: Det værste og det bedste (2003), der er illustreret af Ib Spang Olsens tegninger, samt Tore Ørnsbo: Bastard (2003), der rummer grafik af NG Hammer som modspil til digtene. Og man kan blandt værker, der i sig selv udgør 'kunstbøger' i kraft af samspillet mellem tekst og billede, bemærke Julie og Ursula Andkjær Olsen: Have og helvede (2010), Eva Tind Kristensen: eva + adolf (2011) og Simon Grotrian: Vi ofrer Nathalie (2013) eller som et radikalt eksperimenterende 'lyrikobjekt' Morten Søndergaard: Ordapotek (2010).

Det er bemærkelsesværdigt, hvor forskellige de effekter, der fremtræder i samspillet mellem de to genrer, kan være. I Digital litteratur (2012) fremhæver Hans Kristian Rustad med afsæt i bl.a. Roland Barthes' "Rhétorique de l'image" (1964), W.J.T. Mitchells "Word and Image" (1996) og Jay D. Bolter "The Desire for Transparency in an Era of Hybridity" (2006), et vigtigt begrebspar, der er blevet anvendt til at karakterisere to forskellige relationer mellem tekst og billede (Rustad 2012: 47f.). Hos Barthes tales der om forankring (d'ancrage) vs. udfyldning (de relais), hos Mitchell om konvergens vs. divergens, og hos Bolter om gennemsigtighed (transparency) vs. refleksivitet (reflectivity). Hos de tre teoretikere er der i tilfældet med den første term en harmonisk relation, hvor tekst og billede gensidigt belyser hinanden, mens der i tilfældet med de sidstnævnte begrebspar er et dissonantisk, uafklaret og anfægtende forhold mellem tekst og billede.

Man kan notere sig, at der kun i få af de ovennævnte tekst-billede-relationer, nemlig i tilfældene med Thomsen og Tore Ørnsbo, er tale om, at billedkunsten optræder i en klassisk rolle, hvor man søger at anskueliggøre indholdet af digtene. Den forankrende, konvergerende eller gennemsigtige relation mellem tekst og billede efterlader kun i svag grad betydningselementer, som ikke er umiddelbart afkodelige og forståelige i perceptionsprocessen. Ganske anderledes med Aidts, Vizkis, Tind Kristensens, Andkjær Olsens, Grotrians og Søndergaards værker, hvor der er et kompliceret, uigennemskueligt og provokativt samspil mellem tekst og billeder.

Et eksempel fra Morti Vizkis og Christian Skeels bog viser på den ene side et grafisk billede, hvor en æggeformet figur er overtegnet med pile og omkranset af 14 dødningehoveder, i samspil med en aldeles enigmatisk og mangetydig tekst af Vizki, der lyder: "Hvad har du lavet / I dit unge liv". Et andet af Skeels kunstværker er en kollage med en tegning af Peterskirken i Rom, en udregning af et integrale og teksten "GREEN'S FIRST IDENTITY", i forhold til hvilken Vizki svarer igen med det 
følgende absurdistiske digt: "Han havde været / monteret / på hende".

Det sidste princip er integration. Her indgår flere kunstarter i en syntese og er ikke til at skille ad i værket. Dette gælder for figur- og lyddigte og billedkunst og film med afsæt i montageæstetikken fra den tidlige avantgarde hos bl.a. Hugo Ball, Apollinaire, Kurt Schwitters, Picasso og Sergej Eisenstein og i endnu mere komplekse fusioner i efterkrigstidens eksperimenterende film og teater samt kunstneriske tendenser som happening- og installationskunst. Ser vi herefter på, hvordan det multimodale kommer til udtryk i den digitale poesi, er det tydeligt, at den specielt med hensyn til de to sidstnævnte interartielle principper, kombination og integration, er helt grundlæggende. I nogle af de avancerede værker inden for nordisk digital lyrik, som alle findes på www.afsnitp.dk, såsom Morten Søndergaard: Landskaber omkring digtet kompas (2000), Cia Rinne: zaroum (2001), Malte Persson: Apolloprojektet (2004) og Johannes Heldén: Primärdirektivet (2008) træffer man således særdeles komplekse synteser af tekst, lyd, billede, grafik, animation og film.

\section{Slutord}

Der er naturligvis talrige andre tendenser i den rige interaktion mellem litteraturvidenskab og lyrik, som man har set udfolde sig siden 1990. Der har været en opblusning inden for kognitiv lingvistisk orienteret lyriklæsning med bl.a. Frederik Stjernfelt: Rationalitetens himmel (1997) og Mia Graa: Når ørknen blomstrer. Edith Södergran set i lyset af tre metaforteorier (1999). Man har set en oprustning inden for den editionsfilologiske tradition, hvor man bl.a. har fået Jørgen Hunosøes og Henrik Blichers udgivelse af henholdsvis Sophus Claussens Samlede digte 1-4 (2000) og Schack Staffeldts Samlede digte 1-3 (2006). Man kan nævne en lang række monografier om digtere, hvor fokus også har været på de seneste generationer. ${ }^{2} \mathrm{Og}$ man kan fremhæve retninger som økokritikken, der med Henning Fjørtoft: Jordsanger. $\emptyset$ kokritiske analyser av Inger Christensens lange dikt (2011) uden tvivl vil blive efterfulgt af flere læsninger af den nyeste lyrik.

Det skal desuden understreges, at de opridsede tendenser i lyrikforskningen inden for de sidste årtier på ingen måde er et fænomen, der kun begrænser sig til Danmark. Går vi til de øvrige nordiske lande, finder vi således en vrimmel af afhandlinger og antologier om lyrikere som Jan Erik Vold, Paal Brekke, Edith Södergran, Elmer Diktonius, Kristofer Uppdal, Gunvor Hofmo, Olav H. Hauge, Stein Mehren, Tomas Tranströmer, Rolf Jakobsen, Eva Ström, Jo Eggen og Tor Ulven eller om lyrik i generelle perspektiver. ${ }^{3}$ Hvis en indikator for lyrikkens betydning i Danmark og andre lande derfor er dennes betydning for og interaktion med litteraturvidenskaben, så synes konklusionen at være klar og utvetydig, nemlig at det står særdeles godt til med denne genre.

\section{Noter}

I Blandt eksempler på sådanne værker kan man nævne Knud Wentzel: Utopia. Et motiv i dansk digtning (1990), Bo Hakon Jørgensen: Symbolismen - eller jegets orfiske forklaring (1993), Klaus P. Mortensen: Himmelstormerne. En linie i dansk naturdigtning (1993), Søren Baggesen: Seks 
sonderinger $i$ den panerotiske linie i dansk lyrik (1997), Erik Svendsen: Det nye. Sonderinger $i$ dansk modernisme (1998), undertegnedes Modernistiske outsidere. Underbelyste hjørner af dansk lyrik tradition fra 1800 til i dag (1998), Jan Rosiek: Andre spor. Studier i moderne dansk lyrik (2003), Anker Gemzøe m.fl. (red.): Modernismens historie (2003), Louise Mønster: Nedbrydningens opbyggelighed. Litterære historier i det 20. århundredes nordiske modernistiske lyrik (2009), undertegnedes Drømme og dialoger. To poetiske traditioner omkring 2000 (2009) og Susanne Kemp: Appeller. Estetik i det 20. århundredes danske lyrik (2010).

2 Eksempler på dette er f.eks. Neal Ashley Conrad: Skønheden er en gåde. Søren Ulrik Thomsens forfatterskab (2002), Lars Bukdahl: Læberne sproges. Hokus Pokus F.P. Jac (2005), Dan Ringgaard: Nordbrandt (2005), Sune Auken og Svend Skriver: Dét, der forsvinder, tager jeg med. Søren Ulrik Thomsens poesi og poetik (2011), Dan Ringgaard: Stoleleg. En bog om Jørgen Leth (2012) og Louise Mønster: Mødesteder. Om Tomas Tranströmers og Henrik Nordbrandts poesi (2013).

3 Man kan her nævne forskere som Atle Kittang, Erling Aadland, Per Buvik, Andreas Lombnæs, Unni Langås, Ole Karlsen, Henning Wærp, Sissel Furuseth, Eva-Britta Ståhl, Per Bäckström, Anders Olsson, Roland Lysell, Christian Janss, Arne Melberg, Hans Kristian Rustad, Eirik Vassenden, Christian Refsum, Johan Alfredsson, Niklas Schiöler, Vigdis Ysted, Bill Romefars, Tatjana Brandt, Hadle Oftedal Andersen, Per Erik Ljung og Eva Lilja.

\section{Litteratur}

Bredsdorff, Thomas (1996): Med andre ord. Om Nordbrandts poetiske sprog, København: Gyldendal. Booth, Wayne C. (1983): The Rhetoric of Fiction, London: Penguin.

Brooks, Cleanth (1947): The Well-Wrought Urn: Studies in the Structure of Poetry, London 1947.

Culler, Jonathan (1981): "Apostrophe”, in: The Pursuit of the Signs, Ithaca: Cornell University Press. Engdahl, Horace (2004): Berøringens ABC (1994), København: Gyldendal.

Fafner, Jørgen (1994 og 2000): Dansk vershistorie 1-2, København: Gyldendal.

Fafner, Jørgen (1989): Digt og form, København: Gyldendal.

Hauge, Hans (1994): “O, mening. Om apostrofen hos N.F.S. Grundtvig, Jakob Knudsen og Henrik Nordbrandt”, in: Tania Ørum (red.): Til værks. Dekonstruktion som læsemåde, København: Tiderne Skifter.

Kemp, Susanne (2010): Appeller. Astetik i det 20. århundredes danske lyrik, Odense: Syddansk Universitetsforlag.

Kittang, Atle (1998): "Det billedmæssige" in: Per Krogh Hansen og Jørgen Holmgaard (red.): Billedsprog, Holte: Medusa.

Kjerkegaard, Stefan (2007): Ildspor. Ordspillet og dets funktion i Per Højholts, Simon Grotrians og Peter Laugesens digtning, Odense: Syddansk Universitetsforlag.

Kjørup, Frank (2003): Sprog versus sprog. Mod en versets poetik, København: Museum Tusculanum. Jørgensen, Bo Hakon (2003): Intentionalitet - om litterær analyse på fænomenologisk grundlag, Odense: Syddansk Universitetsforlag.

Larsen, Peter Stein (2001): "O nitroglycerin! Apostrofiske former i ny dansk lyrik", in: (red. Anker Gemzøe, Gorm Larsen og Britta Timm Knudsen) Moderne metafiktion, Holte: Medusa.

Larsen, Peter Stein (2003): "Metonymien i moderne lyrik", in: K\&K 96.

Larsen, Peter Stein (2009): Drømme og dialoger. To poetiske traditioner omkring 2000, Odense: Syddansk Universitetsforlag. 
dansk poesi", in: KRITIK 194.

Mai, Anne-Marie (1998): “The Thrill of It All. Modernismen som mangearmet blæksprutte”, in: KRI-

TIK 135.

Moestrup, Mette (2011): Dø, løgn, dø, København: Gyldendal.

Nielsen, Birgitte Steffen (2002): Den grå stemme. Stemmen i Tomas Tranströmers poesi, Hald: Arena.

Olsen, Ursula og Julie (2010): Have og helvede, København: Gyldendal.

Ringgaard, Dan (2000): “De bundne former og avantgarden", in: Standart nr.1.

Ringgaard, Dan (2000): Den poetiske lækage. Sophus Claussens lyrik, rejsebøger og essayistik, København: Museum Tusculanum.

Ringgaard, Dan (2005): Nordbrandt, Aarhus: Aarhus Universitetsforlag.

Rustad, Hans Kristian (2012): Digital litteratur. En innføring, Oslo: Cappelen.

Sten-Knudsen, Julie (2011): Hjem er en retning, København: Gyldendal.

Sternberg (2011): Et punkt overrendt af ingenting, København: Øverste Kirurgiske.

Stochholm, Nicolaj (2013): Ødelagt rim, København: Gyldendal.

Sørensen, Peer E. (1997): Udløb i uendeligheden. Læsninger i Sophus Claussens lyrik, København: Gyldendal.

Vizki, Morti og Skeel, Christian (2002): Rejsebog, København: Gyldendal.

Vosmar, Jørn (1993): “Værkets verden, værkets holdning”, in: KRITIK 12. 